\title{
Slope instabilities from echo-character mapping along the French Guiana transform margin and Demerara abyssal plain
}

\author{
L. Loncke ${ }^{a,{ }^{*}}$, L. Droz ${ }^{b}$, V. Gaullier ${ }^{a}$, C. Basile ${ }^{c}$, M. Patriat ${ }^{d}$ and W. Roest ${ }^{d}$
}

\begin{abstract}
a Laboratoire IMAGES - Bâtiment U, 2ème Etage, Université de Perpignan Via Domitia, 52 Avenue Paul Alduy, 66860 Perpignan Cedex, France

${ }^{\mathrm{b}}$ UMR-CNRS 6538, Institut Universitaire Européen de la Mer, Place Nicolas Copernic, 29280 Plouzané, France

c Laboratoire de Géodynamique des Chaînes Alpines, UMR-CNRS 5025, Observatoire des Sciences de l'Univers de Grenoble, Université Joseph Fourier, Maison des Géosciences, 1381 rue de la Piscine, 38400 St. Martin d'Hères, France

d Ifremer, DRO/GM - Géosciences Marines, BP70, 29280 Plouzané, France
\end{abstract}

\begin{abstract}
*: Corresponding author : L. Loncke, Tel.: +33 468661745; fax: +33 468662019, email address : lies.loncke@univ-perp.fr
\end{abstract}

\begin{abstract}
:
The French Guiana transform margin and Demerara abyssal plain have been recently surveyed in the framework of the EXTRAPLAC French Program of extension of the continental shelf (Guyaplac survey, Ifremer-IFP-SHOM-IPEV). Based on the interpretation of some of the data collected during the Guyaplac survey (Simrad-EM12 multibeam bathymetric data, backscatter imagery, and $3.5 \mathrm{kHz}$ profiles), the area can be divided into three morphostructural domains.
\end{abstract}

(1) The western Guiana margin, including a part of the Demerara plateau, an important bathymetric relief prolonging the continental platform off Guiana and Surinam. This domain is bounded by (1a) the NW-SE trending northern border of the Demerara plateau which appears quite steep and corresponds to a transform segment of the margin, (1b) the $\mathrm{N}-\mathrm{S}$ eastern border of the Demerara plateau which corresponds to a divergent segment of the margin.

The Demerara plateau shows a segmented morphology, low slope gradients, and a very rough surface (ripples perpendicular to the slope direction). NNW-SSE structural steps seem to correspond to collapses of $100 \mathrm{~km}$ long blocs towards the east. Slumps initiate along these directions. The observed rough bathymetry seems to be related to creeping processes. At a greater scale (seismic data), this part of the margin has been totally destabilized (numerous imbricate transparent masses rooted at about 0.5 s.t.w.t.t. below seafloor). The NW-SE trending northern border of the Demerara plateau corresponds to a cliff-like continental slope, probably slightly smoother than other transform margins (Ghana/côte d'Ivoire margin).

The $\mathrm{N}-\mathrm{S}$ eastern border of Demerara plateau is characterized by numerous small-scale imbricate slumps. Some of these failures seem to be emplaced in the prolongation of the NNW-SSE structural steps identified on the Demerara plateau.

(2) The eastern Guiana margin corresponds to a NW-SE oriented gullied transform margin segment. The associated continental slope is very steep and characterized by numerous imbricate slumps and related debris flows. Some undulated masses, probably corresponding to creeping sediments or to older mass-wasting events are still imprinted on bathymetry. This transform margin segment is nearly entirely destabilized and eroded. 
(3) The Demerara abyssal plain. This domain is characterized eastwards by channels belonging to the Amazon turbidite system and westwards, at the foot of Demerara continental slope, by sediment waves probably created by contour currents.

To conclude, it seems that there is a strong relationship between the structure (transform and divergent segments) and the emplacement of recurrent slope instabilities. These are probably related to the steepness of the slopes but also to subsidence histories generating in some cases huge deepseated collapses of the whole margin. Fluid ascents are common everywhere in the area, probably enhancing slope instability. Their origin is not constrained but the black shales or Cretaceous organicrich layers could be good candidates.

Keywords: Slope instabilities; Transform margin; Creeping; Fluids; Structural heritage

\section{Introduction}

Along continental margins, and especially on their slopes, an important part of sediments is mobilized through gravity instabilities leading to slope failures and associated mass movements. Their importance and recurrence depend on various factors (i.e. lithology, presence of fluids, overpressures, seismicity, tectonic activity, structural inheritance, sedimentary input, eustatism, etc...). Studying slope instabilities has two main issues: to better perform risk assessments (tsunamis, deep cable breakings, deep offshore hydrocarbon exploitation) and more conceptually, to better understand how they participate to the evolution of submarine reliefs and to deep-sea sedimentation processes. Many studies of submarine slope instabilities are focused either on tectonically active areas (see the examples of Marmara sea or Nankai, McHugh et al., 2006, Gazioglu et al., 2002, Yalciner et al., 2002, Cochonat et al., 2002), or on passive margins, nearly exclusively along highlysedimented divergent segments (e.g. Sager et al., 2004, Tripsanas et al., 2004a and b, Sultan et al., 2004, Loncke et al., this volume). Although several 
shear margins exist in the world ( 30\% of passive margins) and present very specific structurations (e.g., Equatorial Atlantic margins, in Gouyet, 1988, Basile et al., 1993, Benkhelil et al., 1995; Davie Fracture Zone, in Mascle and Blarez, 1987; Southern Exmouth Plateau, Lorenzo et al., 1991, Lorenzo, 1997; Agulhas-Falkland Fracture Zone, in Lorenzo and Wessel, 1997; Northeastern Canada, in Reid and Jackson, 1997; and probably a part of the Gulf of Mexico, in Buffler and Thomas, 1994, Pindell, 1985), few studies have up to now focused on the distribution and importance of slides along these margins. Along the Surinam and French Guiana margins, adjacent transform and divergent segments experienced similar sedimentary and oceanographic conditions. They correspond to an ideal field work to assess the impact of structural inheritance on the type and distribution of slope instabilities along transform margins. These margins have been surveyed recently by the GUYAPLAC survey, supported by Ifremer, IFP, SHOM and IPEV, in the framework of the EXTRAPLAC French Program of extension of the continental shelf. The aim of the present study is to characterize mass movements identified during this campaign and their spatial relationships with the inherited structure. In order to get this aim, a detail analysis of morphology, echo-types and their spatial distribution, and a general characterization of the sedimentary architecture and structural features have been carried out.

\section{Geological setting}

\section{Morphology of the Surinam and French Guiana margins}

The Surinam and French Guiana margins are characterized by a wide continental shelf prolonged seaward by a large indentation, the Demerara plateau. The Demerara plateau corresponds to upper and middle slope bathymetric ranges (Figures 1a and 2). The Demerara plateau is 380 $\mathrm{km}$ long and $\sim 220 \mathrm{~km}$ wide from the upper slope (at about $1000 \mathrm{~m}$ of water depth) to the northwestern escarpment, where water depths increase rapidly from 2000 to more than 4500m (lower slope).

The surveyed area discussed in this paper corresponds to the French Guiana margin that includes the northeastern part of the Demerara Plateau (Figures 1 and 2), the eastern Guyana continental slope and the Demerara abyssal plain (Figures 2 and 3). Several morphostructural domains have to be distinguished including: 1) the Demerara plateau itself gently dipping northward; 2) the lower continental slope off the Demerara plateau, the eastern Guiana slope and 3/ the Demerara abyssal plain, which includes eastwards the distal part of the Amazon deep sea fan (Figures 2 and 3). 


\section{Tectonic evolution}

Prior to the opening of the equatorial Atlantic, the Demerara plateau was adjacent to the Guinea plateau (see Erbacher et al., 2004) (Figure 1b). The individualization and shape of the plateau are related to the successive stages of opening of the Atlantic ocean: 1/ During Early Jurassic times, the opening of the Central Atlantic individualized the western edge of the plateau as a divergent margin (Klitgord and Shouten, 1986; Gouyet, 1988; Unternehr et al., 1988); 2/ At the end of early Cretaceous, the Equatorial Atlantic opened as a main transform zone connecting the South and Central Atlantic oceans. During this rifting, the eastern Guiana margin and the northern edge of the Demerara plateau were en échelon transform faults. This interpretation is supported by the steepness of the continental slope, and in the northern part of the Demerara Plateau by en échelon flower structures sealed by an Albian unconformity (Gouyet, 1988). In the whole area, the ocean-continent transition is poorly constrained (Gouyet, 1988).

\section{Sediment architecture, sedimentology and oceanography}

The Guiana margin is located between two major sedimentary sources: the Amazon southeastwards and the Orinoco westwards.

On the Demerara plateau, the post-rift sedimentation consists in successive wedges prograding from the continental shelf, with a maximum total thickness of $6 \mathrm{~km}$ at the foot of the upper continental slope. Northward, most part of the plateau is covered by 2 to $3 \mathrm{~km}$ of sediments. The Cenozoic cover thins or pinches out at the distal escarpment, where Cretaceous deposits outcrop (Gouyet, 1988, Erbacher et al., 2004). The lower part of the post-rift sedimentary cover is tilted landward upslope, horizontal in the middle part of the plateau and tilted seaward towards its northern border (where the sedimentary cover is affected by repetitive seaward collapses). In the abyssal plain, sedimentary thicknesses drastically increase south-eastwards, i.e. towards the Amazon turbidite system (Patriat et al., 2005).

The present-day sedimentology is poorly known, especially in the deep parts of the margin. In the inner continental shelf, Holocene cored sediments consist in homogeneous muds, occasionally with interbedded sands and unconformity surfaces (Mario and Pujos, 1998). Other analysis (Krook, 1992; Mario and Pujos, 1998; Pujos et al., 2001) demonstrate that the marine 
muds deposited on the French Guiana coast mostly originate from the Amazon (sediments transported northwestwards by the Guiana current). Along the Demerara plateau and slopes, the presence of Neogene sediments is rather patchy (Erbacher et al., 2004); most of the recent sedimentary sequence, made of nannofossil ooze, is thin or absent from the distal portions of the plateau where several hiatuses and slump deposits have been evidenced (Erbacher et al., 2004). Thicknesses of the sedimentary sequence generally increase towards the smoother sector of the Demerara plateau. On this plateau, older clay rich sediments (Upper Miocene to Pliocene) are attributed to Amazon sedimentary plumes (Erbacher et al., 2004). Finally, in the abyssal plain, the only available data concerning sedimentary records come from Piper et al. (1997) (ODP leg 155). On the most western core site of this leg (at a distance of $100 \mathrm{~km}$ from the study zone), levee sandy sediments belonging to the distal Amazon fan are overlain by 25m of Holocene calcareous clays and bioturbated muds.

The oceanography is characterized by three major water masses, that may influence sediment dispersal along the French Guiana margin (Stummel and Arons, 1960; Schmitz and McCartney, 1993; Hogg et al., 1996; Hogg and Owens, 1999; Dengler et al., 2004): 1/ the AAIW (Antartic Intermediate Water) remobilizing sediments northward between 800 and 900m water depth, 2/ the NADW (North Atlantic Deep Water) and associated DWBC (Deep Western Boundary Current) remobilizing sediments southeastward from $\sim 2500$ to $4300 \mathrm{~m}$ water depth, 3/, the AABW (Antartic Bottom Water) remobilizing sediments northwestward at $\sim 4600 \mathrm{~m}$ with complex pathways characterized by gyres that change in time and space.

\section{Methodology}

The French Guiana margin (i.e. the western Guiana margin including the eastern part of Demerara plateau, and the eastern Guiana margin) has been surveyed in 2003 during the GUYAPLAC cruise onboard the R/V l'Atalante (Figure 2). The dataset comprise EM12-Simrad multibeam bathymetry (Figure 3) and backscatter imagery (Figure 4), recorded together with $3.5 \mathrm{kHz}$ profiles. $3.5 \mathrm{kHz}$ profiles have an average penetration of $50 \mathrm{~m}$ below seafloor. Bathymetric data have been processed using CARAIBES software developed by IFREMER (Figure 3) with a main $250 \mathrm{~m}$ resolution grid. Additional processing has been performed along the Demerara plateau where we reach a $125 \mathrm{~m}$ resolution grid. In addition, 6 channels seismic data has been acquired along tracklines at a speed of 8 knots. This seismic data will be poorly discussed in this paper.

The Data analysis included three phases 
1/ Morpho-structural and morphosedimentrary analysis of bathymetry and acoustic imagery in order to point out the main bathymetric directions, escarpments and sedimentary structures,

2/ Classification and interpretation of $3.5 \mathrm{kHz}$ echo-characters on the basis of (i) acoustic penetration and continuity of bottom and sub bottom reflectors, (ii) microtopography of the sea floor, and (iii) internal structures.

3/ Mapping of the morphological features and classified 3,5 kHz echo-characters.

\section{II.Classification of echo-characters}

Nine echo-types and subtypes have been defined and are grouped into four main types (Figure 5):

1. Bedded echo-characters include distinct bottom echo-types with: a. Parallel continuous subbottom reflectors that can be deformed after deposition (B1); b. Bedded-wavy echo-types corresponding to regular undulated bottom echo-types with parallel wavy depositional subbottom reflectors (B2); and c. Bedded-rough echo-characters (B3) corresponding to bottom echo-types with parallel highly reflective near-surface reflectors and poor penetration.

2. Rough echo-characters include: a. Rough echo-types (R1) corresponding to prolonged sharp bottom echo-types without subbottom reflectors; In the abyssal plain, these echo-types are frequently characterized by small incisions due to channel pathways.

3. Hyperbolic echo-characters are expressed either by large, irregular hyperbolic bottom echoes without subbottom reflectors (H1) or by small regular hyperbolic bottom echoes without subbottom reflectors (H2).

4. Transparent echo characters (T) include all echo-types that display weak bottom echoes with a transparent subbottom and a reflective erosive base. This echo-type can be buried or not under bedded deposits. In some cases, several transparent masses are stacked up.

5. Chaotic echo characters (C) correspond to weak, wavy bottom echo-types with chaotic discontinuous subbottom reflectors and rough and strong surficial echoes.

It happens frequently that these echo-types are perturbed by seismic wipe-outs due to the presence of fluids or gas. This will be discussed in part IV (Results).

Based on numerous studies of seafloor sampling providing a basis for allocating specific sedimentary types and, finally, depositional processes for most of the echo-types (Figure 5), we 
speculate the following links between echo-characters, type of sediments and associated depositional processes:

- Continuous bedded echo-characters (B1) are commonly attributed to detrital sediments deposited by turbidity currents, with alternating sandy and silty beds (Damuth, 1980a, Pratson and Laine, 1989). However, these echo-types may also indicate hemipelagic deposits (Gaullier and Bellaiche, 1998). In some cases, these echo-characters can be deformed after deposition by gravity processes such as slumping, creeping or gliding.

- Bedded wavy echo-types (B2) are generally attributed to sediment waves generated by deep currents reworking turbiditic and/or hemipelagic sediments (Bouma and Treadwell, 1975; Jacobi et al., 1975; Damuth 1979, 1980b).

- Bedded-Rough echo-types (B3) are generally attributed to turbidites, coarser than those of the B1 echo-type. Damuth (1975) and Damuth and Hayes (1977) have shown that a quantitative relationship exists between the relative abundance of coarse, bedded terrigeneous sediment (silt/sand/gravel) in the upper few meters of the sea floor and the B1, B3, and R echo-types. According to these authors, regions characterized by R echotypes have sediments that contains the highest concentrations of coarse terrigeneous sediments (distal lobes for example), whereas the sediments of regions characterized by B1 echo-types contain little coarse sediments. The R echo-types also can be attributed to regions where erosional processes are dominant, such as in channel axes.

- Hyperbolic echo characters have different meanings depending on the size, shape and spacing of the hyperbolae. The occurrence of hyperbolae is mainly linked to the degree of roughness of the sea floor topography. Large, irregular hyperbolae (H1) are generally associated with rough topographies such as seamounts, basement highs, fault scarps, and rugged slopes, which mask the underlying echo-facies. Small regular hyperbolae (H2) are commonly associated with deposits and surface structurations generated by mass-wasting processes (Damuth, 1980a, b, 1994).

- Transparent echo-characters (T) commonly correspond to deposits due to mass-flow processes: most debris flows return relatively diffuse, fuzzy echo-types from their upper surfaces. Their internal structure generally lacks coherent reflectors and appears acoustically transparent (Embley, 1976, 1980; Jacobi, 1976; Damuth, 1980a, b, 1994) while their erosive base appears reflective. Transparent echo-types can also characterize basinal fine-grained turbidites (Tripsanas et al., 2004b., Cita et al., 1984), but without an erosive base. 
- Chaotic echo-characters (C) correspond to highly-disorganized sediments generally induced by mass-wasting processes such as slumping or debris flows (Pratson and Laine, 1989; Damuth, 1994).

Although some echo-characters can be specific for sediments and associated depositional processes (eg. transparent echo-types with characterized by an erosive base, that generally correspond to debris flows), a same sedimentary process can be expressed by various echo-types (e.g., destabilized deposits may be imaged by both transparent and chaotic echo-characters). Alternatively, bedded-wavy (B2) echo characters can look very similar to bedded (B1) when deformed, although the first one corresponds to sediment waves and the second one for example to creeping sediments. Finally, it is common to observe a downslope deformational evolution, and one instability event can be characterized from upslope to downslope by a rough failure scar, a bedded faulted initiation area and a transparent debris flow. Consequently, echo-types must be placed in their physiographic and geological context before attempting any correlation to a given depositional process.

\section{Results}

Analysis of sub-surface data (bathymetry, acoustic imagery, and $3.5 \mathrm{kHz}$ echo-characters) reveals a great variability of slope instabilities and sedimentary processes in the different domains of the margin (see domains on Figure 6):

\section{Physiographic domains \& Morphosedimentary features The Demerara plateau}

The Demerara plateau is gently dipping seawards. At a regional scale, the plateau is affected by at least four "en échelon" NNW-SSE trending slope breaks giving a "stair" aspect to the plateau (Figure 6). These directions parallel the transform trends. The most important NNW-SSE trend corresponds to the foot of the upper slope. One NE-SW lineament, parallel to the divergent margin cuts the plateau. The surface of the Demerara plateau is characterized by numerous ripples perpendicular to the slope suggesting active or recent instability processes (Figure 6). Several positive and negative reliefs (circular or elongated) could correspond to fluid-related structures (mud volcanoes and pock-marks) or remoblized blocks. Some elongated depressions could in particular correspond to giant pock-marks (some of them reaching $2 \mathrm{~km}$ in diameter and $100 \mathrm{~m}$ depth) reshaped by deep-sea currents as on the Norwegian slope (see Boe et al.,1998). 
Here, the DWBC (Stummel and Arons, 1960; Dengler et al., 2004) could be a good candidate for elongating pock-marks towards SE. On backscatter imagery, there is no evidence of active sedimentary transits seen the area appears very homogeneous. Resolution of imagery doesn't allow to discuss the activity of possible fluid-related structures (Figure 4).

\section{The northern border of the Demerara plateau (transform segment)}

The northern border of the Demerara plateau shows slope gradients decreasing from west to east (Figure 6). Its western part is gullied. Going eastwards, the slope becomes smoother (Figure 6). Again, there is no evidence of active sedimentary pathways on backscatter imagery (Figure 4).

\section{The eastern border of the Demerara plateau (divergent segment)}

The eastern border of Demerara plateau is mainly characterized by the termination of the NNWSSE trends observed on the plateau and by several imbricate slumps (20km long in average), some of them affecting the interfluve of canyon-like features (Figure 6). They seem to be particularly important in the prolongation of NNW-SSE slope breaks affecting the Demerara plateau, suggesting a structural control. Unfortunately, the orientation of Guyaplac seismic lines does not allow to better constrain this hypothesis. As on the Plateau and its northern slope, there is no evidence of active sedimentary transits (Figure 4).

\section{The Eastern Guiana slope (transform segment)}

On this transform segment of the margin, our data set does not image the transition from the platform domain to the shelf break, but only the continental slope and its transition to the abyssal plain (Figure 6). On available seismic lines, this part of the continental slope seems to have been totally destabilized by repetitive slope failures (Figure 7). Shaded bathymetry and slope gradient maps show that the upper continental slope is totally gullied by sub-parallel small canyons, without hierarchized networks (Figure 6). The transport network becomes hierarchized downslope, with very large (up to $5 \mathrm{~km}$ ) U-shaped active canyons (Figure 6). It is noteworthy that there is a change in canyons directions in the glacis: eastward, they are perpendicular (NESW-trending) to the continental slope, westward, they are oblique, trending N-S, probably because of a more important subsidence in the vicinity of the Demerara Plateau. Finally, the seafloor shows rippled lobate masses in a $100 \mathrm{~km}$-wide zone at the slope foot (Figure 6).

\section{The Abyssal plain}

The abyssal plain corresponds to water depths of 4000m and more. It is less imaged by our dataset than the slope domains. Two types of remarkable features can be recognized: 1 / northward, 
an elongated depression probably of oceanographic/sedimentary origin and 2/ southeastwards, small meandering fossil channels probably belonging to the nearby Amazon deep-sea fan.

\section{Echo character analysis and distribution}

\section{The Demerara plateau}

The Guiana continental shelf and Demerara plateau (Figure 8) are mainly made of bedded sediments (B1). All over the plateau, many seismic wipe-outs suggest the presence of important fluid circulations. These wipe-outs are perturbing different types of sediment layers (bedded or transparent) and could be at the origin of the different circular topographies observed on bathymetry (see previous section).

- Along the little part of the continental shelf imaged during the survey, sediments are uniformly bedded. In some areas, diffracting features characterize sediment beds (see green dots on figure 8 for location). These could correspond to buried crusts (carbonate? ferruginous?) or sandy dunes. Finally, in some areas, sediments appear tilted landward and sealed by an erosive surface (effect of the Guiana current?).

- On the Demerara plateau, echo-characters are mainly Bedded (B1) and deformed. One small transparent debris flow affects the plateau (in blue on Figure 8). A general upslope to downslope evolution suggesting regional mass movements has been observed on regional $3.5 \mathrm{kHz}$ profiles ( 100 km long) (Figure 9). Upslope, slumps initiate along the uppermost NNW-SSE scarp. Downslope, these slumps evolve to asymmetrically deformed sediments (compressive toe of the slump or more likely creeping sediments). The sediments then thin distally together with a diminution of slope gradients corresponding on 3-5 khz to a rough to transparent mass sometimes showing seismic wipe-outs (fluids?) (Figure 9). These regional mass movements are confirmed by seismic data on which the Demerara plateau appears to have been nearly entirely destabilized (Figure 7). Several imbricate glided masses affect in average the last $500 \mathrm{~m}$ sediments. It seems like these structures correspond to the slide of hecto-kilometric bodies towards the northeastern border of the plateau. Surface destabilizations observed on surface data correlate in consequence with deep, massive collapses. Whether the deformations observed on surface are the imprint of ancient events or active features is unclear. Seen the freshness of deformations and importance of fluid ascents, we believe that the whole plateau is experiencing seaward creeping processes. Finally, numerous diffracting structures (purple stars on Figure8) 
have been observed along the plateau. We interpreted these tentatively as buried chaotic reliefs (due to mass movements) or cold seep related structures.

\section{The northern border of the Demerara plateau (transform segment)}

Echo-character mapping shows that the western gullied zone corresponds to slope failures giving rise at the foot of the scarp to transparent deposits (debris flows) of small extent (Figure 8). Eastwards, echo-characters are bedded (B1) and affected by undulations that could correspond to the creeping of the sedimentary cover.

\section{The eastern border of the Demerara plateau (divergent segment)}

In terms of echo-characters, this area is mainly characterized by bedded echo-types only tilted within imbricate slumps observed on bathymetry (Figure 8). Numerous seismic wipe-outs have been observed in the vicinity of slope instabilities.

\section{The Eastern Guiana slope (transform segment)}

The echo-character mapping of this area reveals the presence of several recent slide complexes (transparent or chaotic echo-types) separated by areas of bedded facies showing undulations (Figure 8). The bedded undulated areas correspond on bathymetry to the rippled lobate masses. Most of the recent debris-flows complexes cut these lobate masses and are bathymetrically lower, suggesting that these lobate deformed sediments are either remnants of older slide complexes or sediments slowly creeping seaward. When analysing in details some slide complexes, destabilization events appear repetitive as observed by the imbrication of at least three transparent debris-flow in the most eastwards sector of the study area (Figure 10). This slide complex, extending along $150 \mathrm{~km}$ perpendicular to the margin, is the most important of this part of the margin.

Evidences of fluid ascents are very common through the sediments. These fluid ascents affect indifferently the "stable" lobate masses and the recent destabilized masses, questioning the relation between fluids and slope instabilities. However it is frequently observed that seismic wipe-outs are located above buried transparent debris-flows, suggesting that a part of the observed fluids are generated by the dewatering of debris flows during later sedimentary overloading (Figure 10). Such dewatering processes may activate later creeping of the 
sedimentary cover. Similar scenarios have already been suggested in the case of the Nile and Congo deep-sea fans (Bayon et al., submitted; Gay et al., 2004).

\section{The Abyssal plain}

The abyssal plain shows few recent remobilized deposits except at the foot of the eastern continental slope (Figure 8). $3.5 \mathrm{kHz}$ echo-characters evolve distally from bedded (B1) to bedded-rough (B3) probably because of increasing proportion of coarser sand deposits (Figure 7). These facies are associated with small meandering fossil channels probably belonging to the Amazon deep-sea fan (Figure 8). This observation suggests the existence of Amazon channelized deposits $100 \mathrm{~km}$ further west of what was proposed by Piper et al., 1997. No other channelized detritic arrivals have been observed in the abyssal plain. The absence of sedimentary input from the Guiana shelf is probably related to the disconnection of deep-sea environments from river mouths during high sea-levels.

At the northern foot of the Demerara plateau, asymmetrically undulated echo-types probably correspond to sediment waves that we associated with deep-bottom currents (Figure 8). As a matter of fact, this sediment wave field occurs along an elongated depression suggesting transport by contouritic currents of sediments. However, Gonthier et al., (2002) recognized more or less in the same area sediment waves made of alternations of fine-grained turbiditic deposits and less important hemipelagic deposits. These sediment waves correspond to fine grained turbiditic deposits associated with the Orinoco deep-sea fan (the Orinoco river mouth lies 150 km further west). Alternatively, the northwestwards AABW could also be responsible for these structures.

As in the other morphostructural domains of the margin, the abyssal plain is affected by numerous fluid ascents (Figure 11), except in the distal coarser areas (bedded-rough and roughchannelized echo-types).

\section{Discussion and conclusions}

\section{Relationships between sedimentary/instability processes and structural heritage}

Slope instabilities are particularly abundant and impressive in size and volume along the French Guiana margin. It may be surprising as this margin is rather poorly sedimented, but it enhances the importance of structural control in the shaping and evolution of submarine domains. 
Although submitted to similar sedimentation rates, the various segments of the margin, either transform (Northern Demerara plateau and Eastern Guiana slope) or divergent (Eastern Demerara plateau), exhibit contrasting slope instabilities. The volumes, nature, driving mechanism and probably ages vary from one segment to another:

- The whole Demerara plateau is affected by slumping and creeping processes (Figure 12). These events seem recurrent, and define blocks as wide as $100 \mathrm{~km}$. The driving mechanism seem to be the tilting of the Plateau in relation with increasing subsidence northeastward. This tilting allows the upper part of the sedimentary section to slide on decollement layers sub-parallel to the bedding. This instabilities have been observed in surficial sediments but also on seismic data (seaward collapse of the last 500 meters of sediments).

- Along the Northern slope of the Demerara Plateau, only small debris flows occurred, probably initiated by submarine erosion of the steepest scarps along this transform segment (Figure 12). The lack of massive debris flows may indicates that the sliding of the sediments on the Demerara Plateau did not evolve, at least recently, in catastrophic failures. However, destabilizations intensify northwestward, off Surinam, as the transform border of the Demerara Plateau becomes higher and steeper (Gouyet, 1988; Erbacher et al., 2004).

- East of the Demerara Plateau, the divergent segment seems much more stable. It is only characterized by small-scale imbricate slope scars (blocks of $\sim 5 \mathrm{~km}$ in extension) (Figure 12). While not constrained by seismic data, these structures seem to be controlled by the surficial faults that bound the sliding blocks on the Demerara Plateau. A deeper structural control is also possible. It seems like the southern part of Demerara plateau bounded by a NE-SE fault and by the continental slope, is also collapsing, probably because of differential subsidence rates between the transform (sharp oceancontinental transition) and divergent segments (progressive ocean-continental transition).

- The Eastern Guiana slope is affected by massive and repeated destabilizations (Figure 12), with slope failures generating large debris flows, reworked by creeping processes. The main cause of these slope failures is probably the steepness of this transform continental margin.

When comparing these results to those of other transform margins, and in particular to the African Equatorial margins, some similarities can be depicted. The Côte d’Ivoire margin has indeed undergone important slope instabilities through time (DeCaprona, 1992) and the very steep Ghanaian margin is also characterized by important volumes of mass wasting deposits 
in the abyssal plain (Mascle et al., 1996), suggesting the "chronic instability" of transform margins.

\section{Other recent geologic processes}

From seismic wipe-outs and diffracting circular features, fluid ascents appear to be widespread along the whole margin and the adjacent abyssal plain (Figure 12). Our data set does not allow any speculations concerning the origin of the fluids, but good candidates could be the black shales or Cretaceous organic-rich layers on the Demerara Plateau (Erbacher et al., 2004). In any case, these fluid ascents seem to be closely related with slope instabilities, either along bounding faults acting as drains, or by surficial dewatering of debris flows.

Finally, in the abyssal plain, sedimentation seems to be controlled by four phenomenons: $1 /$ the western detrital input from the Orinoco, apparently generating sediment waves (Gonthier et al., 2002); 2 / the southeastern detrital input from the Amazon deep sea fan; 3 / the unquantified effect of deep bottom currents associated with the northward movement of AABW water mass, and 4/ the interfingering of mass-wasting deposits, especially at the foot of steep transform segments. These mass-flows may be the main type of sediments deposited along transform continental margins, and their emplacement, associated to U-shaped valleys, reworking and dewatering, will probably require more specific studies.

\section{ACKNOWLEDGMENTS}

- We would like to thank Ifremer/IFP/Shom/IPEV for giving access to this data set and the French Research Program “GDR Marges” for supporting this project.

- We also deeply thank Gemma Ercilla \& Jean Benkhelil for their very useful reviews and comments.

\section{References}

Basile C., Mascle J., Popoff M., Bouillin J. P., Mascle G., 1993. The Ivory Coast-Ghana transform margin : a marginal ridge structure from seismic data. Tectonophysics, 22, 1-19.

Bayon, G., Loncke, L., Dupré, S., Caprais, J.-C., Ducassou, E., Duperron, S., Etoubleau, J., 
Foucher, J.-P., Fouquet, Y., Gontharet, S., Henderson, G.M., Huguen, C., Klaucke, I., Mascle, A., Migeon, S., Olu-Le Roy, K., Ondréas, H., Pierre, C., Sibuet, M., Stadnitskaia, A. and Woodside, J., M., 2007. Fluid seepage on an unstable margin: The case of the Centre Nile fan. Submitted to Marine Geology, Special ESF Issue (July 2007).

Benkhelil J., Mascle J., Tricart P., 1995. The Guinea Continental Margin: an example of structurally complex transform margin. Tectonophysics, 248, 117-137.

Boe R., Rise L and Ottesen D., 1998. Elongate depressions on the southern slope of the Norwegian Trench (Skagerrak): morphology and evolution. Marine Geology 146, 191-203.

Bouma, A. H. and T. K. Treadwell, 1975. Deep-sea dune-like features. Marine Geology, 19, M53-M59.

Buffler, R.T. and Thomas, W.A., 1994. Crustal structure and evolution of the southeastern margin of North America and the Gulf of Mexico basin. In: R. Speed (Editor), Phanerozoic evolution of North American continent-ocean transitions. Geology of North America. Geological Society of America, Boulder, Colorado, 219-263.

Cita, M. B., Beghi, C., Camerlenghi, A., Kastens, K. A., McCoy, F. W., Nosetto, A., Parisi, E., Scolari, F., Tomadin, L., 1984. Turbidites and megaturbidites from the Herodotus abyssal plain (Eastern mediterranean) unrelated to seismic events. Marine Geology, 55, 79-101.

Cochonat P., Cadet J.P., Lallemant S., Mazzotti S., Nouzé H., Fouchet C., Foucher J.P., 2002. Slope instabilities and gravity processes in fluid migration and tectonically active environment in the eastern Nankai accretionary wedge (Kaiko - Tokai'96 cruise). Marine Geology, 187, 193202.

Damuth, J.E., 1975. Echo-character of the western equatorial Atlantic floor and its relationships to the dispersal and distribution of terrigenous sediments. Marine Geology, V.18, p.17-45.

Damuth, J. E., 1979. Migrating sediment waves created by turbidity currents in the Northern South China Basin. Geology, 7, 520-523. 
Damuth, J. E., 1980a. Use of high-frequency (3.5-12 kHz) echograms in the study of nearbottom sedimentation processes in the deep-sea: a review. Marine Geology, 38, 51-75.

Damuth, J. E., 1980b. Quaternary sedimentation processes in the South China Basin as revealed by echo-character mapping and piston-core studies: The Tectonic and Geologic Evolution of Southeast Asian Seas and Islands. Geophysical Monograph, American Geophysical Union, 23, 105-125.

Damuth, J. E., 1994. Neogene gravity tectonics and depositional processes on the deep Niger delta continental margin. Marine and Petroleum Geology, 11, 320-346.

Damuth, J. E., and Hayes, D. E., 1977. Echo-character of the East Brazilian continental margin and its relationship to sedimentary processes. Marine Geology, 24, 73-95.

De Caprona G., 1992. The continental margin of western Côte d'Ivoire: structural framework inherited from intra-continental shearing, 150p, Publ A 69., ISBN 91-7032-685-1.

Dengler M., Schott F.A., Eden C., Brandt P., Fischer J., Zantopp R.J., 2004. Break up of the Atlantic deep weastern boundary current into eddies at 8º S. Nature, 432, 1018-1020.

Embley, R. W., 1976. New evidence for occurrence of debris-flow deposits in the deep-sea. Geology, 4, 371-374.

Embley, R. W., 1980. The role of mass transport in the distribution and character of deep-ocean sediments with special reference to the North Atlantic. Marine Geology, 38, 23-50.

Erbacher, J., Mosher, D.C., Malone, M.J. et al. 2004. Proceedings of the Ocean Drilling Program, Initial Reports, 207, 94p.

Gaullier, V. and G. Bellaiche, 1998. Near-bottom sedimentation processes revealed by echocharacter mapping studies, northwestern Mediterranean basin. AAPG bulletin, 82, 1140-1155.

Gay, A., Lopez M., Cochonat P., Sermondadaz G., 2004. Polygonal faults-furrows system related to early stages of compaction - Upper Miocene to present sediments of the Lower Congo Basin. Basin Research, 16, 101-116. 
Gazioglu C., Gökasan E., Algan O., Yücel Z., Tok B., Dogan E., 2002. Morphologic features of the Marmara Sea from multi-beam data. Marine Geology, 190, 397-420.

Gonthier, E., Faugères, J.C., Gervais, A., Ercilla, G., Alonso, B., Baraza, J., 2002. Quaternary sedimentation and origin of the Orinoco sediment-wave field on the Demerara continental rise (NE margin of South America), Marine Geology, 192, 189-214.

Gouyet, S., 1988. Evolution tectono-sédimentaire des marges guyannaise et Nord-Brésilienne au cours de l'ouverture de l'Atlantique Sud. PhD Thesis, univ Pau et des pays de l'Adour, 374 pp.

Hogg N.G and Owens W.B., 1999. Direct measurement of the deep circulation within the Brazil basin, Deep-sea Research II, 46, 335-353.

Hogg N.G., Owens W.B., Siedler G., Zenk W., 1996. Circulation in Deep Brazil Current. In: Wefer. G, Berger W.H., Siedler G; Webb D.J. (Eds), The South Atlantic: Present and Past Circulation. Springer, Berlin, pp. 249-260

Jacobi, R. D., P. D. Rabinowitz, and R.W. Embley, 1975. Sediment waves on the Moroccan continental rise. Marine Geology, v. 19, M61-M67.

Jacobi, R. D., 1976. Sediment slides on the Northwestern continental margin of Africa. Marine Geology, 22, 157-173.

Klitgord, K.D. and Schouten, H., 1986. Plate kinematics of the central Atlantic. In: P.R. Vogt and B.E. Tuckolke (Editors), The western North Atlantic Region (The Geology of North America, vol. M) Geol. Soc. Am. Boulder, CO, 351-377.

Krook L., 1992. Evidence of Amazon provenance of a part of the sandy sediments in the coastal and shelf areas of the Guianas. In : Prost Marie-Therese (Ed.). Evolution des littoraux de Guyane et de la zone caraïbe méridionale pendant le quaternaire. Paris : ORSTOM, 1992, 307-325. 
Lorenzo J., Mutter J.C., Larson R.L. and the NW Australia study group, 1991: “Development of the continent-ocean transform boundary of the southern Exmouth plateau. Geology), 19, 8, 843846.

Lorenzo, J.M., 1997. Sheared continent-ocean margins: An overview. Geo-Marine Letters 17, 13.

Lorenzo, J.M., Wessel P., 1997. Flexure across a continent-ocean fracture zone: The northern Falkland Plateau, South Atlantic. Geo-Marine Letters. 17, 110-118.

Mario P., Pujos M., 1998. Origin of late Holocene fine-grained sediments on the French Guiana shelf. Continental Shelf Research, 18, 1613-1629.

Mascle J., \& Blarez E., 1987. Evidence for transform margin evolution from the Ivory CoastGhana continental margin. Nature, 326, 378-381.

Mascle J., Lohmann G. P., Clift P., \& al, 1996. Proc. of ODP, Init. Rept 159, College Station, TX, (Ocean Drilling Program), 616 pp.

McHugh C.M.G., Seeber L., Cormier M.H., Dutton J., Cagatay N., Polonia A., Ryan W.B.F., Gorur N., 2006. Submarine earthquake geology along the North Anatolia Fault in the Marmara Sea, Turkey: A model for transform basin sedimentation. Earth and Planetary Science Letters, 248, Issues 3-4, 661-684.

Patriat M., Loubrieu B., Vially R., Roest W.R., 2005. The Guyaplac survey, off French Guyana, American Geophysical Union, Fall Meeting 2005, abstract \#T13D-0505.

Pindell, J.L., 1985. Alleghenian reconstruction and the subsequent evolution of the Gulf of Mexico, Bahamas: proto-Caribbean Sea. Tectonics, 4, 1-39.

Piper D.J.W, Flood R.D., Cisowski D., Hall F., Manley P.L., Maslin M., Mikkelsen N., and W. Showers, 1997. Synthesis of tratigraphic correlations of the Amazon fan, p 595-609, in Flood, R.D., Piper D.J.W., Kaus A., and Peterson (Eds.), Proceedings of the Ocean Drilling Program, Scientific Results, 155. 
Pratson, L. F., Laine, E. P., 1989. The relative importance of gravity-induced versus currentcontrolled sedimentation during the Quaternary along the MidEast U.S. outer continental margin revealed by 3.5 kHz echo-character. Marine Geology, 89, 87-126.

Pujos M., Pons J.C., Mario P., 2001. Les minéraux lourds des sables du littoral de la Guyane française : bilan sur l'origine des dépôts de la plate-forme des Guyanes. Oceanologica Acta, 24 (Suppl.), S27-S35.

Reid and Jackson, 1997. A review of three transform margins off eastern Canada, Geomarine letters, 17, 87-93.

Sager W.W., MacDonald I.R., Hou R., 2004. Side-scan sonar imaging of hydrocarbon seeps on the Louisiana continental slope. AAPG Bulletin, 88, 725-746.

Schmitz W.J., McCartney M.S., 1993. On the North Atlantic circulation. Rev. Geophy. 31, 29-49

Sultan N., Cochonat P., Cayocca F., Bourillet J.F., Colliat J.F., 2004. Analysis of submarine slumping in the Gabon continental slope. AAPG Bulletin, 88, 781-799.

Stummel H, Arons A.B., 1960. On the abyssal circulation of the world ocean-I. Stationary planetary flow patterns on a sphere. Deep-Sea Research, 6, 140-154

Tripsanas E.K., Bryant W.R., Phaneuf B.A., 2004a. Slope-instability processes caused by salt movements in a complex deep-water environment, Bryant Canyon area, northwest Gulf of Mexico . AAPG Bulletin, 88, 801-823.

Tripsanas E.K., Bryant W.R., Phaneuf B.A., 2004b. Depositional processes of uniform mud deposits (unifites), Hedberg Basin, northwest Gulf of Mexico: New perspectives. AAPG Bulletin, 88, 825-840.

Unternehr, P., Curie D., Olivet J.L., Goslin J., and Beuzart P., 1988. South Atlantic fits and intraplate boundaries in Africa and South America. Tectonophysics, 155, 169-179. 
Yalciner A.C., Alpar B., Altinok Y., Özbay I., Imamura F., 2002. Tsunamis in the sea of Marmara. Historical documents for the past, models for the future. Marine Geology, 190, 445463.

\section{Vitae}

Lies Loncke received her Ph.D from university of Paris 6 (Marine Geology) in 2002 and is now assistant professor with the University of Perpignan (France). Her research focuses since her Ph.D. on parameters controlling the deep-sea structure and evolution (especially salt tectonics, deep-seated tectonics, sediment dispersal processes, fluid escapes, slope instabilities) and also on the interpretation of satellite images in active tectonic settings (Baikal, New-Zealand).

Laurence Droz received her PhD in 1983 and her HDR in 1991 both from the University Paris 6. She is a Researcher at the CNRS, since 1983, presently at the Laboratory "Domaines Océaniques" (UMR 6538 of CNRS and University of Brest, France). She is a specialist in gravity sedimentation, and especially on the architecture and evolution of turbidite sytemes, and their controlling factors.

Virginie Gaullier received her Ph.D. in Marine Geology from the University Paris 6 in 1993 and is an Assistant Professor at the University of Perpignan, France. Virginie's current research work uses geophysical data and analog modeling to study the interaction between sedimentation and gravity-driven deformation in deep-sea fans with emphasis on salt tectonics and masswasting processes.

Christophe Basile received his Ph.D. in Marine Geology from the University Paris 6 in 1990. He has been assistant professor, then professor in University Joseph Fourier (Grenoble) since 1992. His main research topic was the evolution of transform continental margins. Current researchs are focused on interaction of volcanism and sedimentation on continental margins, and on structural data processing from borehole imaging.

Walter Roest received his $\mathrm{PhD}$ in Marine Geophysics from the University of Utrecht in the Netherlands in 1987. After a postdoctoral fellowship at the Bedford Institute of Oceanography in Nova Scotia, he joined the Geological Survey of Canada in Ottawa in 1990. His research focuses on global plate tectonic processes and continental margin evolution, as well as on the use of 
magnetic and gravity data for crustal scale studies. Since 2003, he is director of Ifremer's Marine Geosciences department in Brest, France, and leader of the French continental shelf programme related to the UN Law of the Sea.

Martin Patriat received his Ph.D. in structural geology and metamorphism from the University Paris 6 in 1996. During several postdoctoral and assistant professor positions at the University Paris 6, the University of Corse, IFP and Ifremer, he worked on various thematics, ranging from late orogenic extension to basin subsidence, oceanic island geology and geophysics. In 2005, he joined Ifremer's Marine Geosciences department in Brest, France, to work for the French continental shelf programme related to the UN Law of the Sea.

\section{Figure Captions}

Figure 1: A. Location and geological setting of Guiana and Surinam margins (modified after Gouyet, 1988). The area explored during Guyaplac survey is indicated by the box on the right side. B. Reconstruction of the central Atlantic during the Albian time (Gouyet, 1988, modified from Unternehr, 1986).

Figure 2: Tracklines of Guyaplac survey. Location of seismic lines and 3,5 kHz profiles shown in Figures 7, 9, 10.

Figure 3: Bathymetric map of the Guiana Margin. Isobaths every 100 meters.

Figure 4: Backscatter imagery of the Guiana Margin. High reflectivity is indicated in dark grey.

Figure 5: Classification of $3.5 \mathrm{kHz}$ echo-types. Each echo type has particular meanings and is generally associated with specific sediment types generated by specific sedimentary processes.

Figure 6: Color shaded bathymetry of Guyaplac data. Detail A is focused on imbricated slumps along the divergent segment. Detail B is focused on the Demerara plateau showing a quite rough surface. Detail C is a 3D view of two elongated depressions probably corresponding to giant pock-marks. 
Figure 7: Seismic lines from Guyaplac. The upper profile cuts the Demerara plateau and its northern border. The lower profile cuts the eastern Guiana slope (location on Figure 2). A and B are details of regional slope instabilities affecting both margin segments.

Figure 8: Echo-character map. Each color represents a specific echo-type (for echo-types, refer to figure 5).

Figure 9: 3.5 kHz profile across the Demerara plateau. Location on Figure 2.

Figure 10: $3.5 \mathrm{kHz}$ profiles along the eastern Guiana slope. Location on Figure 2.

Figure 11: Examples of fluid ascents (seismic wipe-outs on $3.5 \mathrm{kHz}$ data) in the abyssal plain and eastern Guiana slope.

Figure 12: Synthetic map of sedimentary processes and distribution of fluid ascents (in yellow). 
(A.)

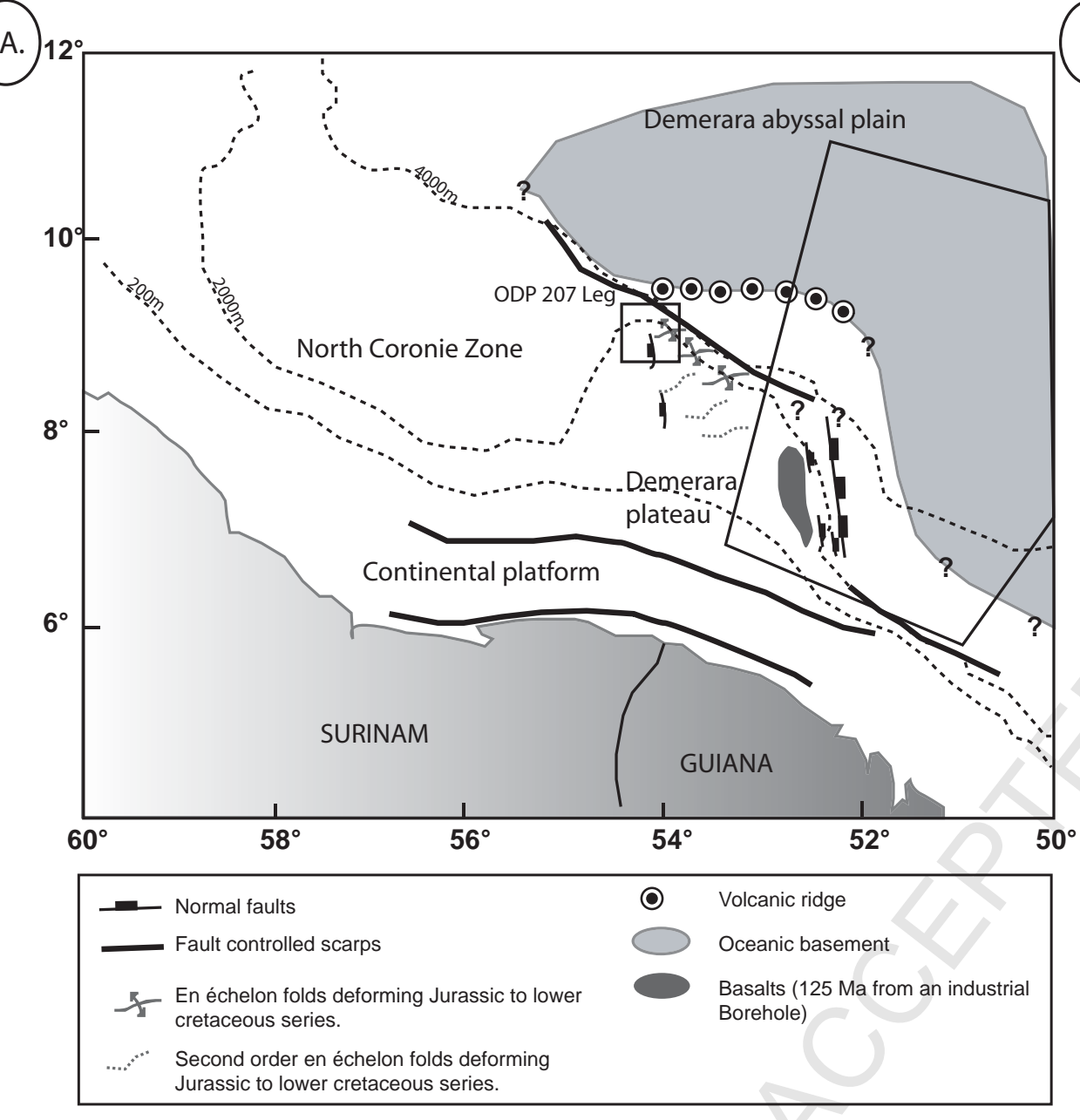

B.

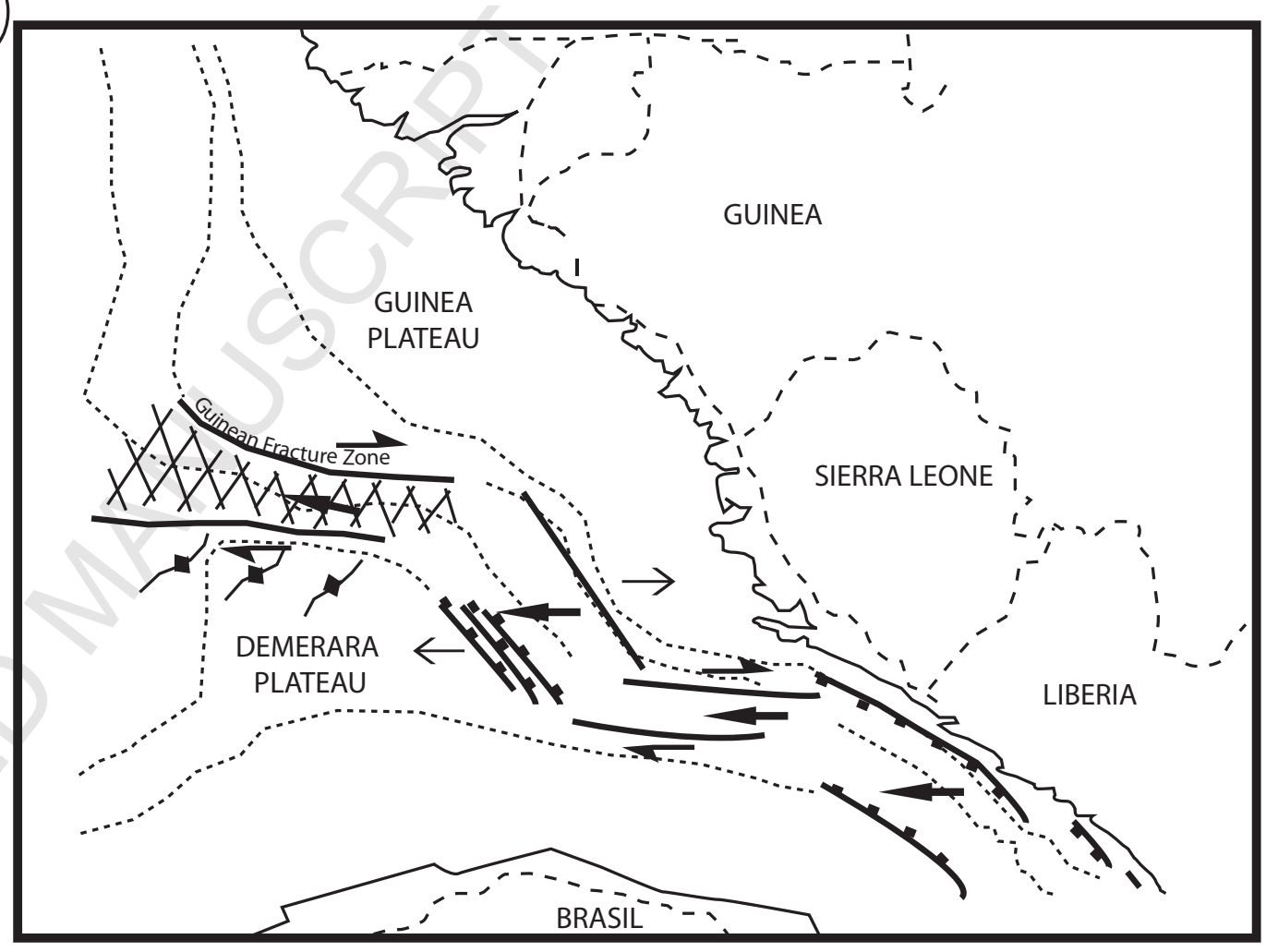

South America/Africa motion during Neocomian and Albian times.

X Strike slip fault zone $\underset{\longleftrightarrow}{\rightleftharpoons}$ Relative movements.
Folds 


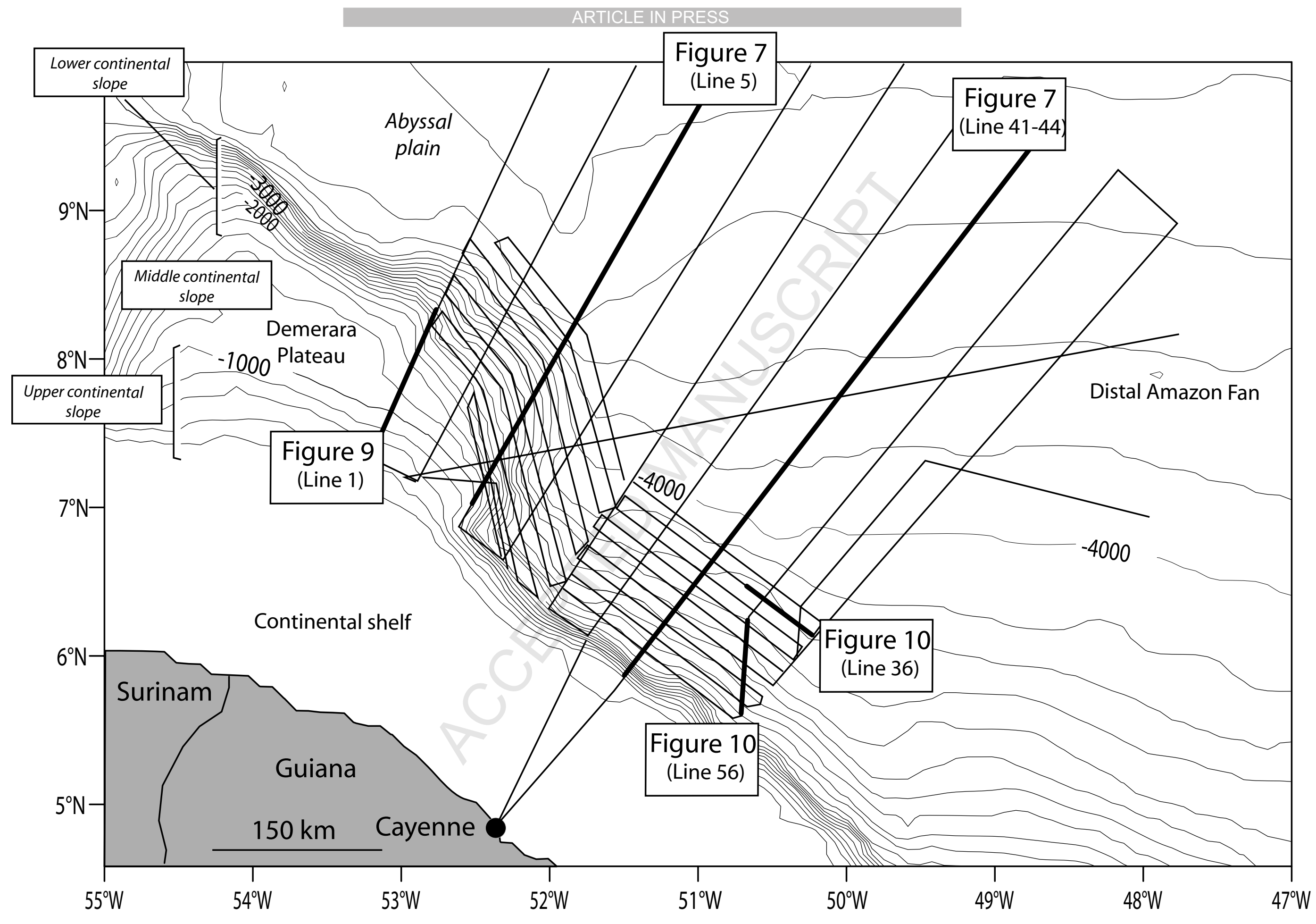




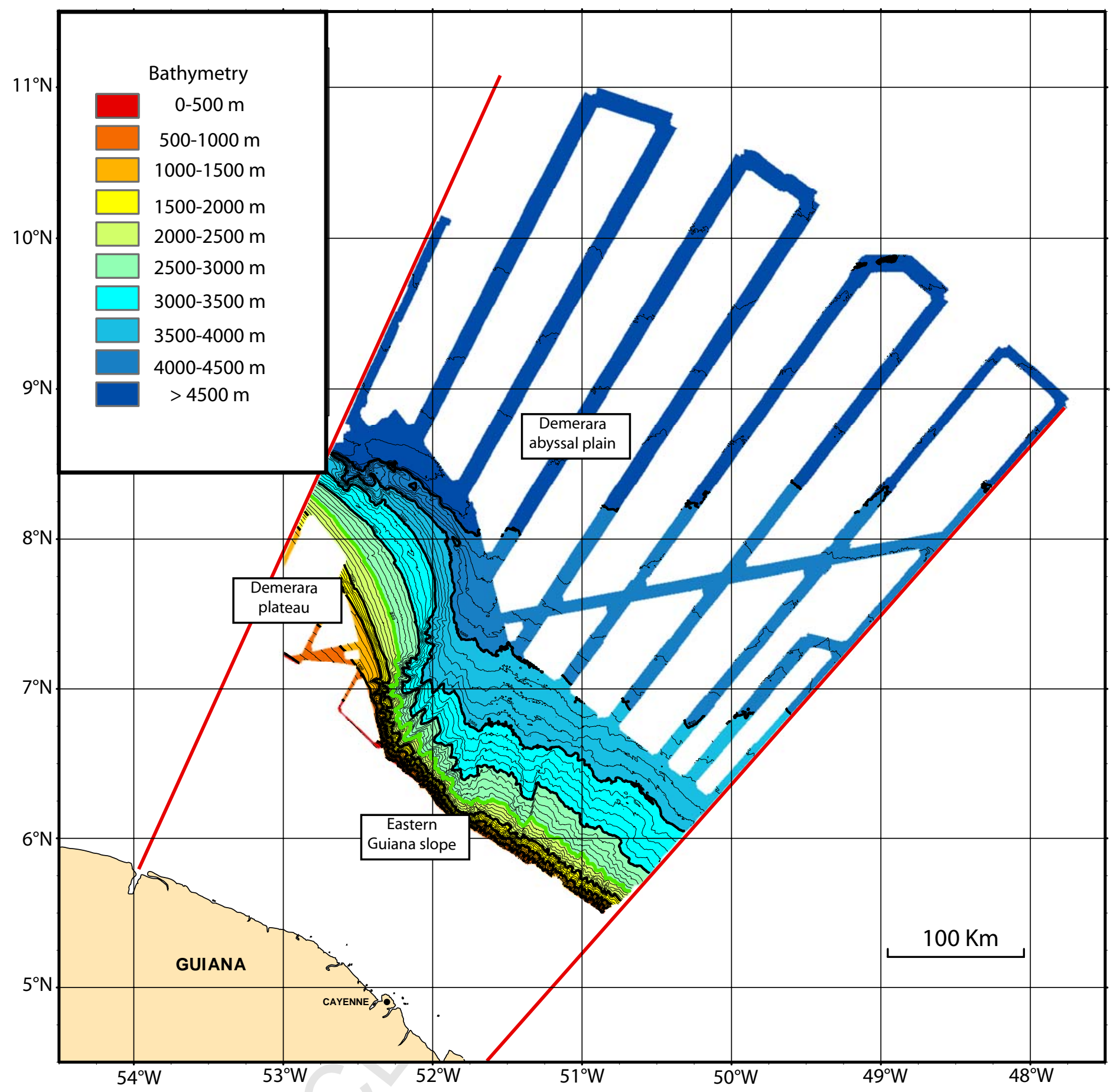




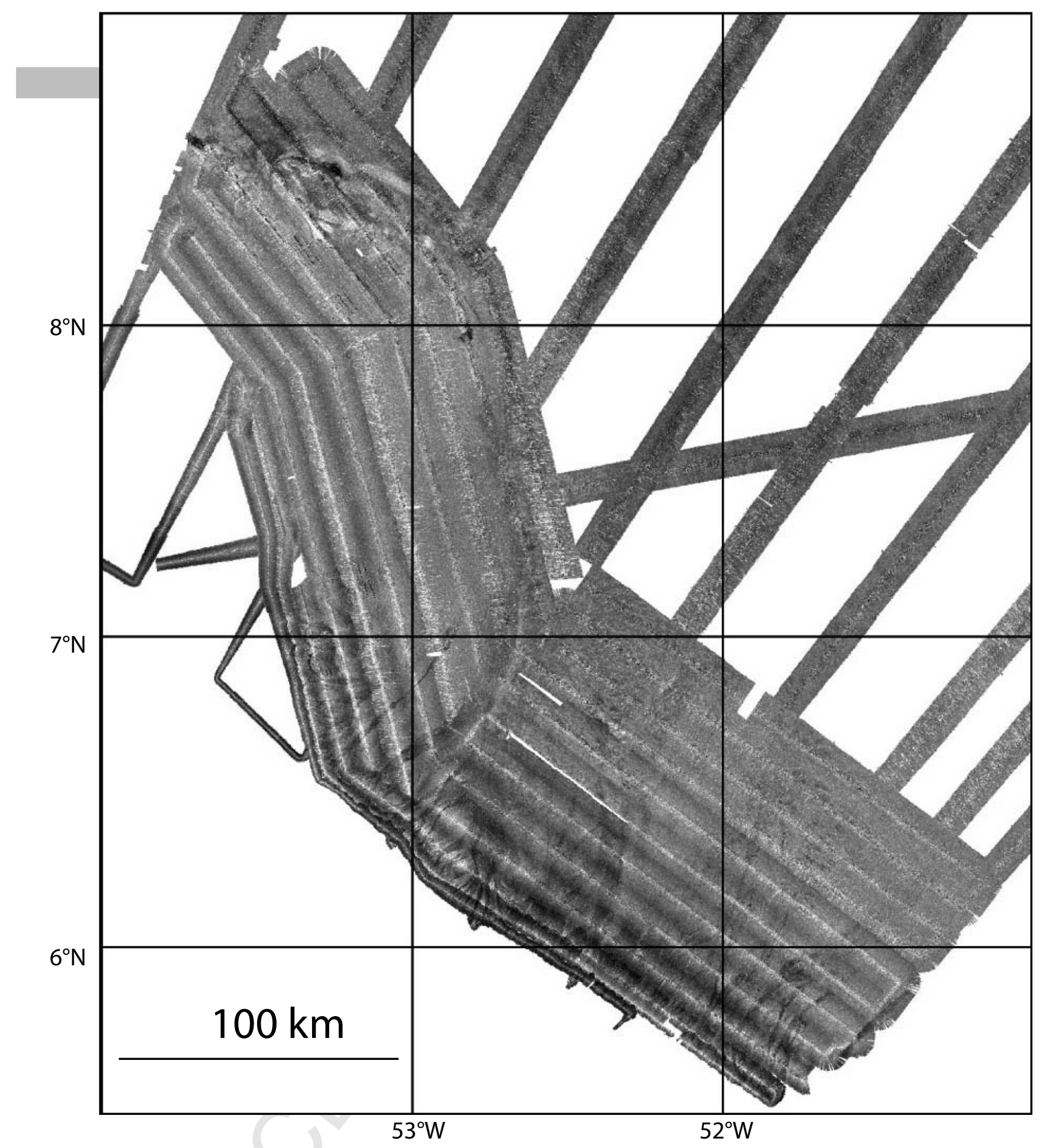




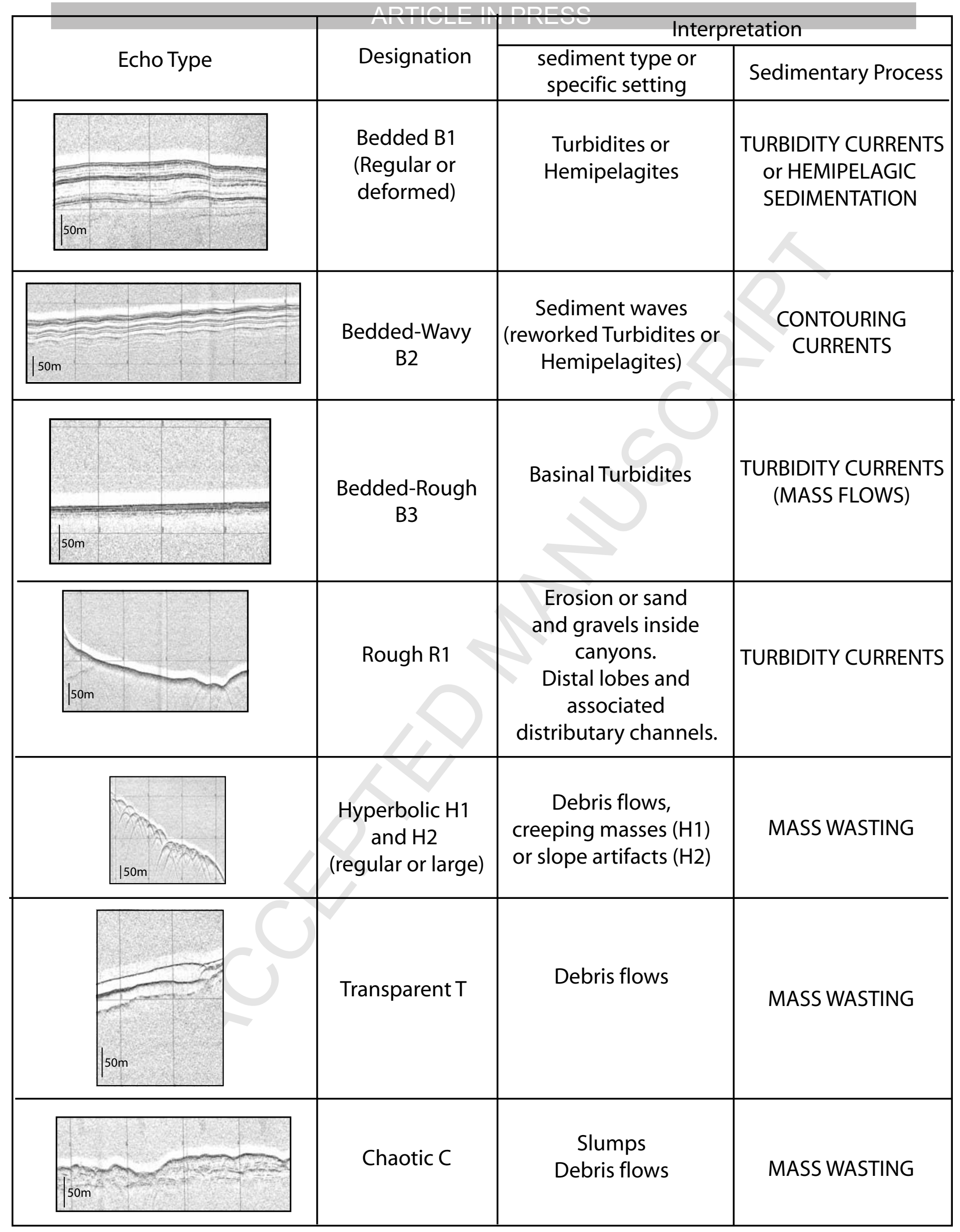




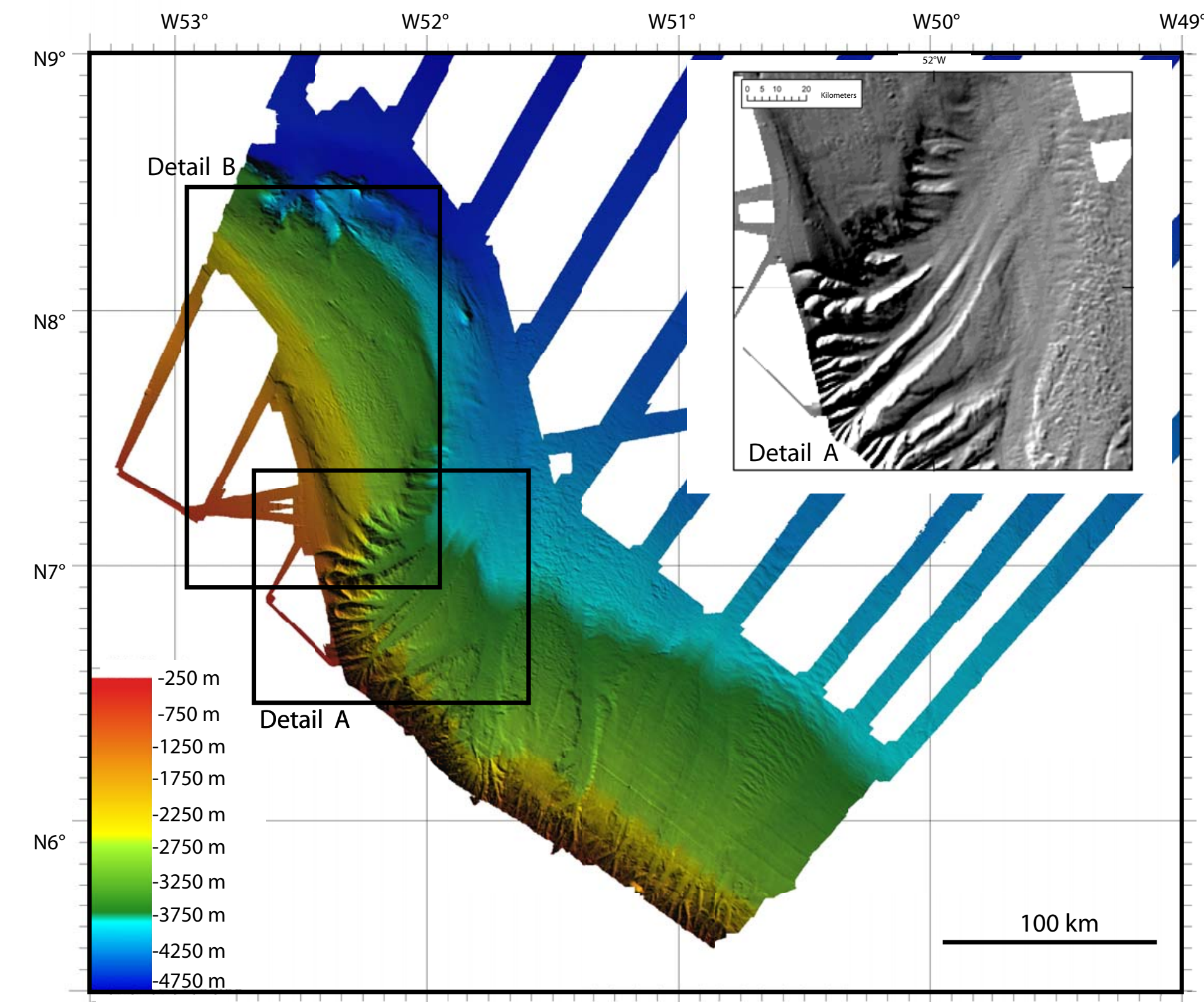

Detail B
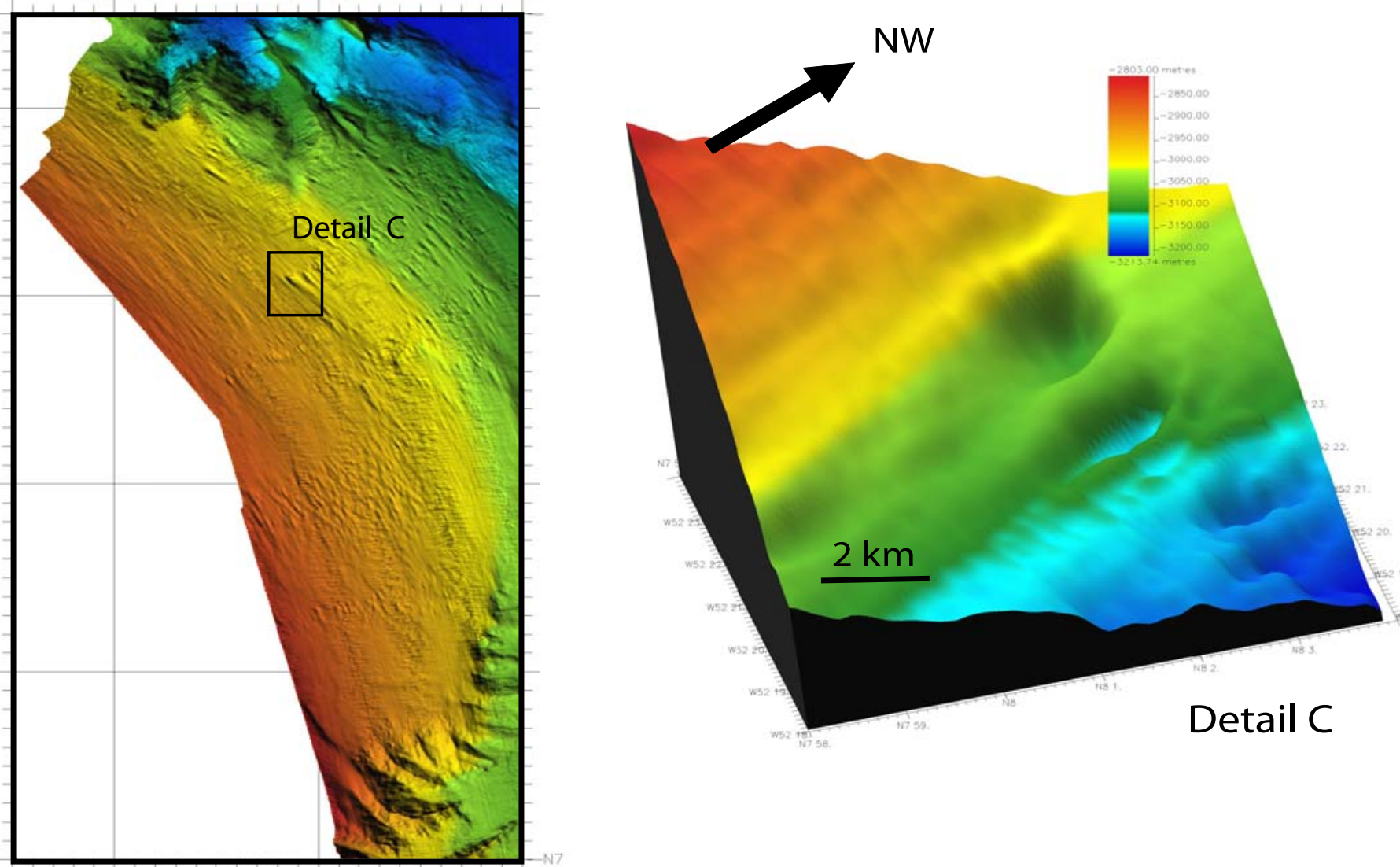

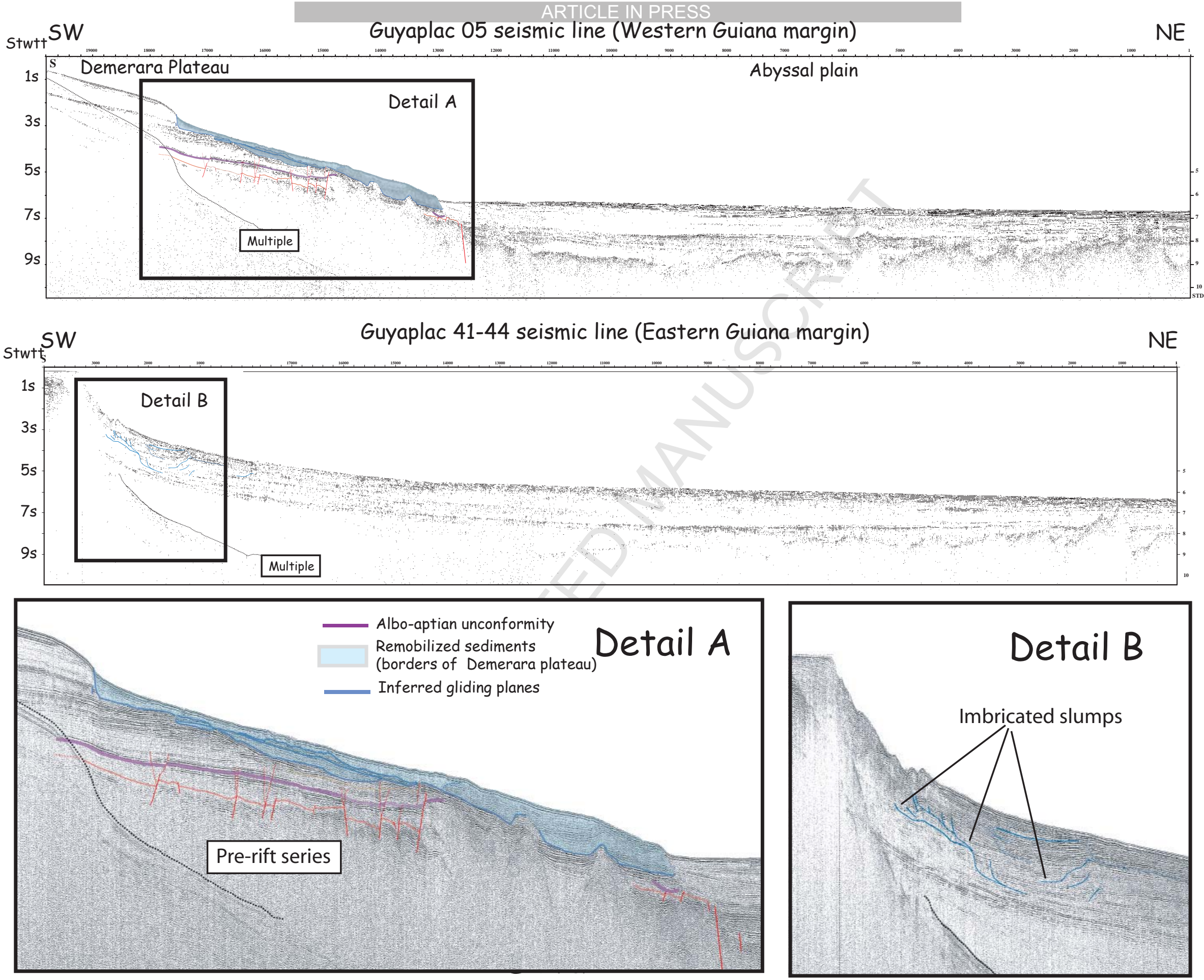
$53^{\circ} 0^{\prime} 0 " \mathrm{O}$

$52^{\circ} 0^{\prime} 0^{\prime \prime O}$

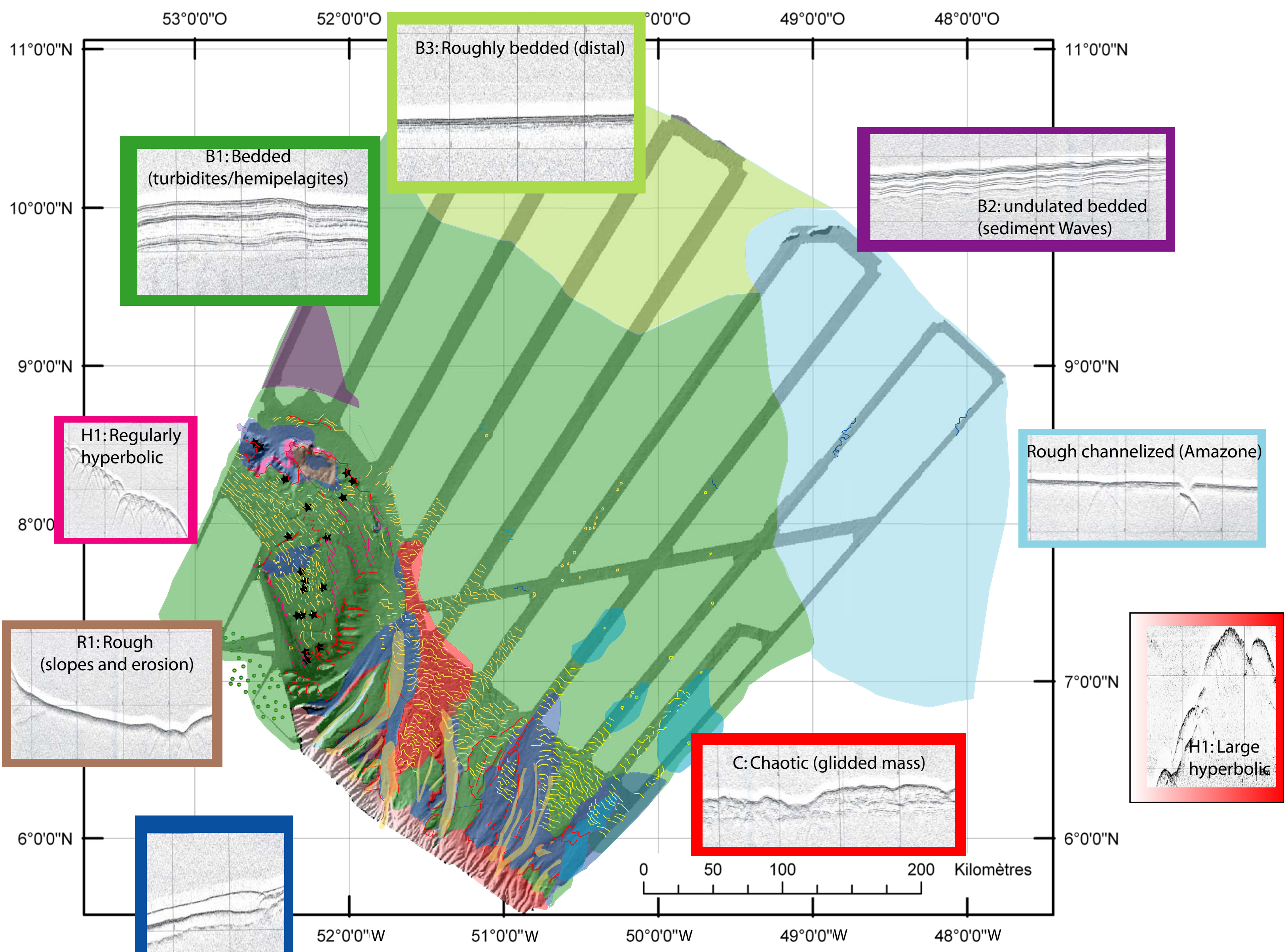

T:Transparent

(debris flows)

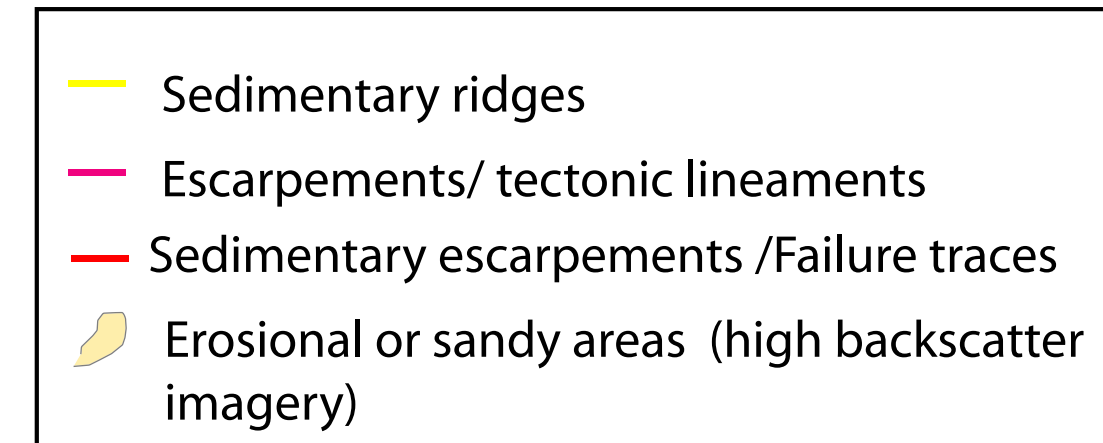

Circular reliefs (pock-marks?)

2 Channels

- Diffracting features inside sediment beds (crusts?)

$\downarrow$ Diffracting hyperbolas (buried reliefs? Seeps?) 


\section{Detail A Slide Initiation}

GUYAPLAC, Line 1

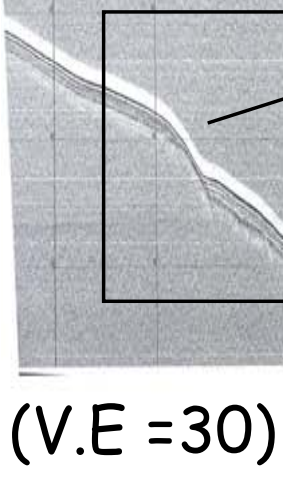
area

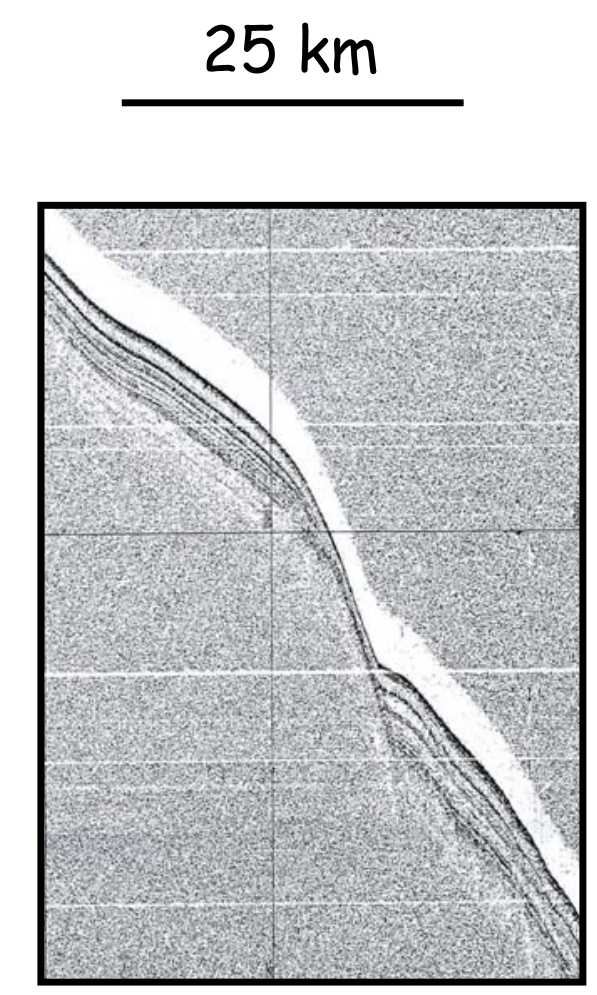

Detail A

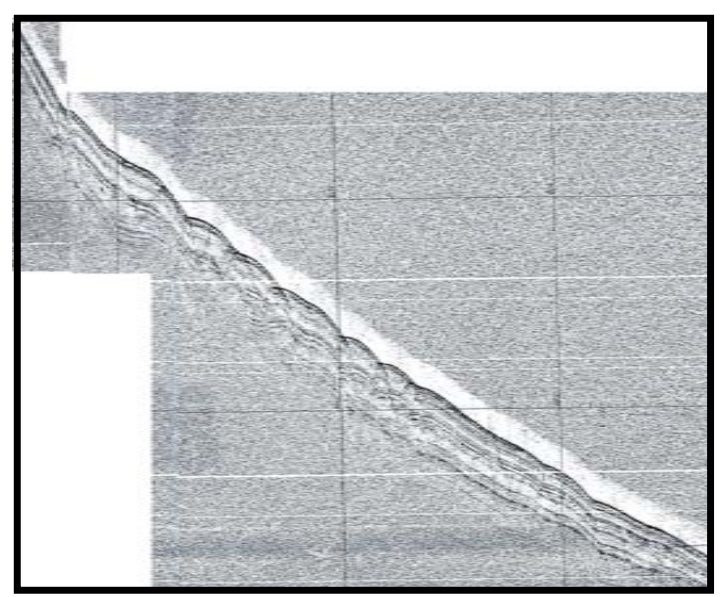

First ridges

(creeping? Compressional zone?)

vertical pipes (fluids?)

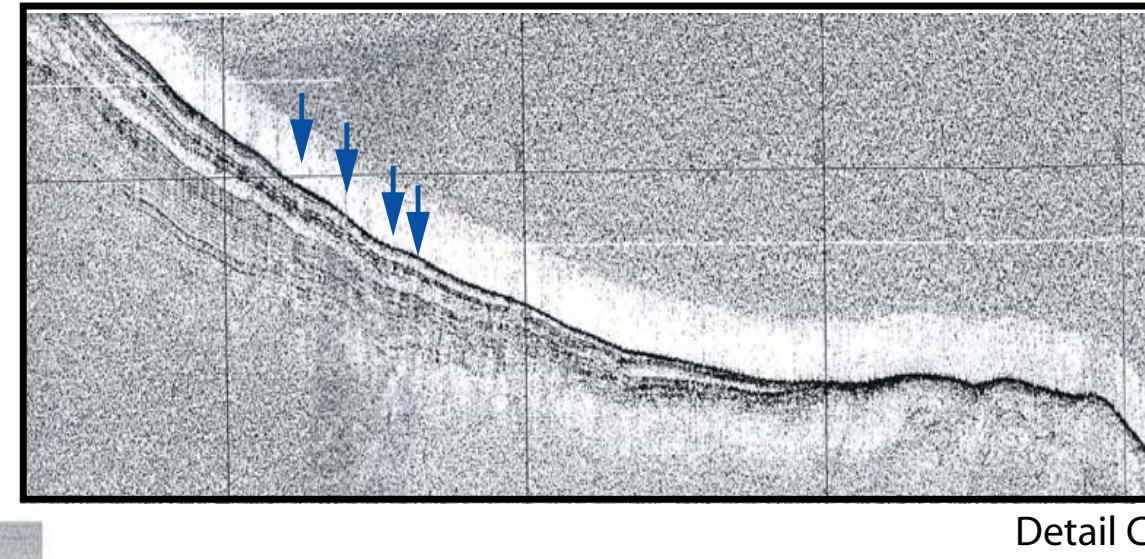

Detail B

Outcropping transparent body + vertical pipes (fluids?)
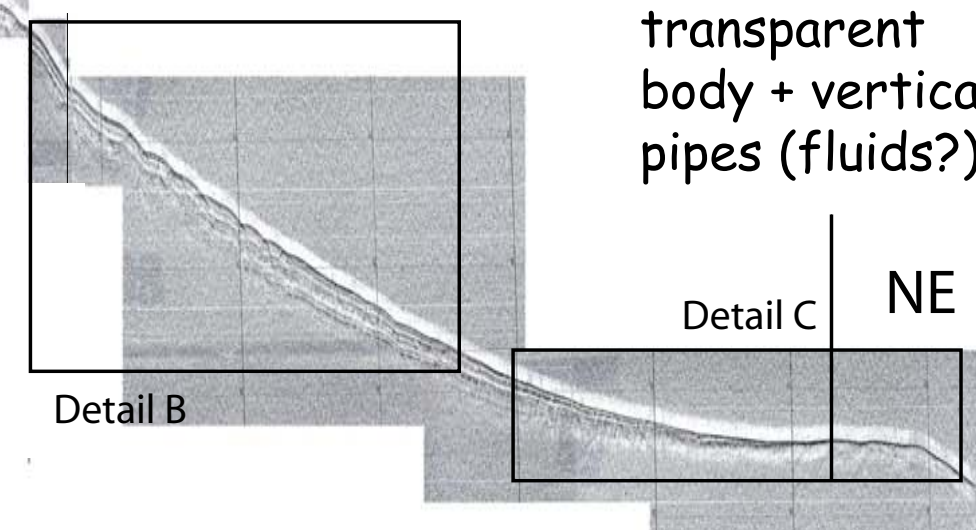

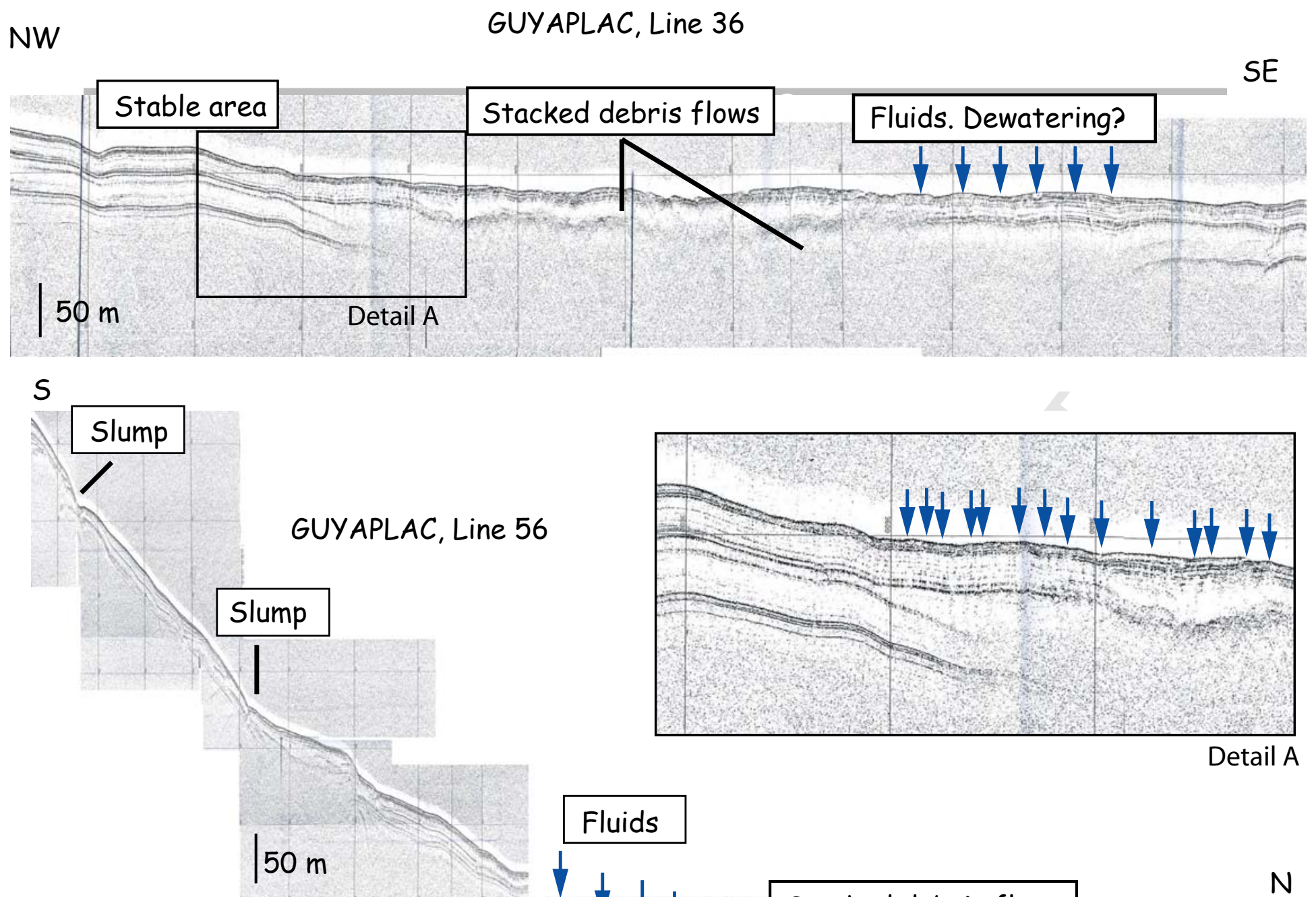

\section{Fluids}

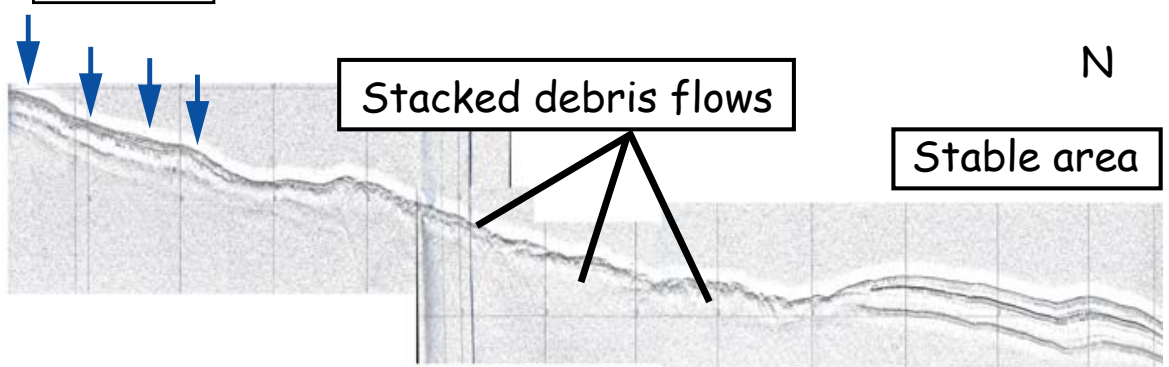




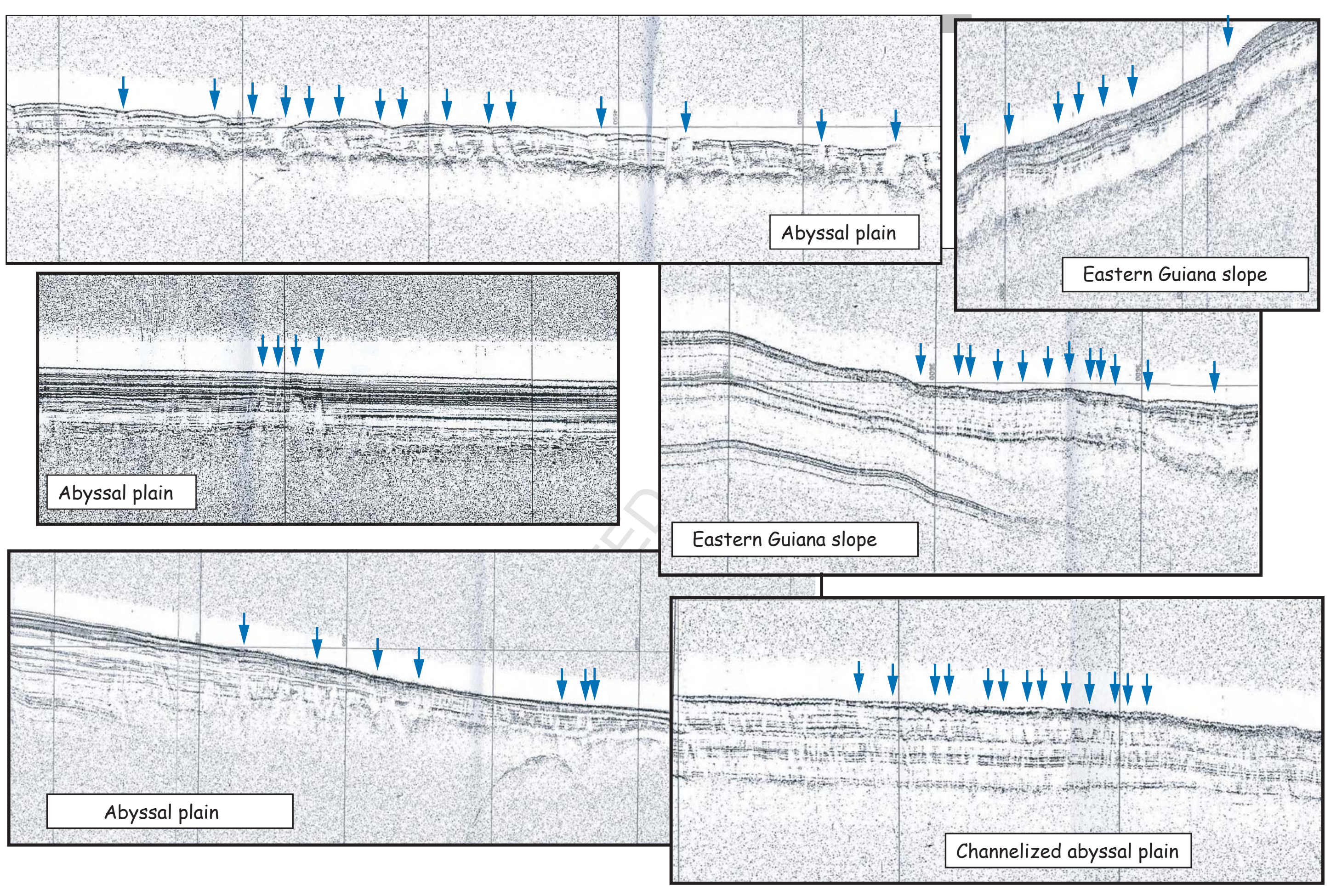




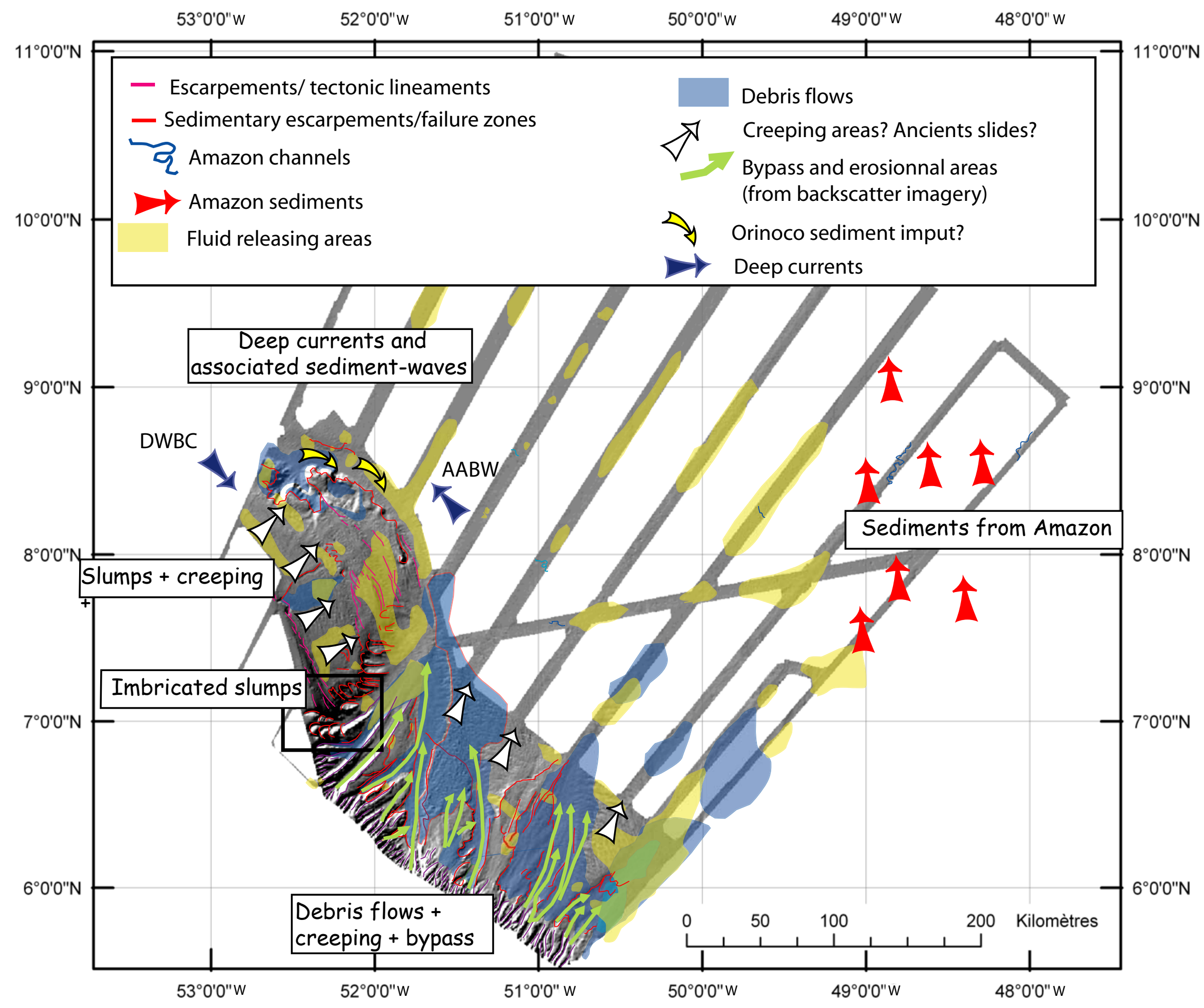

